\title{
$\mathrm{Zn}_{2} \mathrm{SnO}_{4}$ の焼結に及ぼす添加物の影響
}

\author{
松下徹*・島田志郎* - 小平紘平* \\ 山并孷**・輪 島一郎*** \\ $\left(\begin{array}{ccc}* & \text { 北海道大学 } \text { 工学部 } & \text { 応用化学科教室 } \\ * * \text { 名古屋大学 工学部 } & \text { 応用化学科教室 } \\ * * * \text { 日本電装 }(\text { 株) } & \end{array}\right.$
}

\section{Effects of Oxide Additives on Sintering of $\mathrm{Zn}_{2} \mathrm{SnO}_{4}$}

\author{
By \\ Toru MATSUSHITA*, Shiro SHIMADA*, Kohei KODAIRA*, \\ Iwao YAMAI**, and Ichiro WAJIMA**** \\ Department of Applied Chemistry, Faculty of Engineering, \\ Hokkaido University \\ ** Department of Applied Chemistry, Faculty of Engineering, \\ Nagoya University \\ *** Nippon Denso Co.
}

\begin{abstract}
The effects of $\mathrm{V}_{2} \mathrm{O}_{5}$ and $\mathrm{B}_{2} \mathrm{O}_{3}$ additives on the densification of $\mathrm{Zn}_{2} \mathrm{SnO}_{4}$ have been discussed from the results of the isothermal shrinkage and grain size measurements. Compacts pressed at $400 \mathrm{~kg} / \mathrm{cm}^{2}$ were sintered in the range of 1200 to $1400^{\circ} \mathrm{C}$ in air. The shrinkage was determined by measuring the diameter of the compacts before and after sintering, and the grain size in the sintered compacts was measured by the electron microscopy. The results of the shrinkage measurement without oxide additives indicated that the densification in the initial stage is controlled by the bulk diffusion with the activation energy of $130 \mathrm{kcal} / \mathrm{mol}$. The rate of grain growth was found to be followed by the equation, $D^{3}=K t$ ( $D$ : diameter of grain, $K$ : rate constant, $t:$ time), and the value of its activation energy was estimated to be 150 $\mathrm{kcal} / \mathrm{mol}$.

It was found in the case of the $\mathrm{V}_{2} \mathrm{O}_{5}$ and $\mathrm{B}_{2} \mathrm{O}_{3}$ additives that the densification can be represented by three processes which are typical of the densification in the liquid phase; the first: rearrangement, the second: solution-precipitation, the final: coalescence, and that the liquid phase of $\mathrm{V}_{2} \mathrm{O}_{5}$ and $\mathrm{B}_{2} \mathrm{O}_{3}$ greatly accelerates the densification of $\mathrm{Zn}_{2} \mathrm{SnO}_{4}$ via these processes. The rate of the second process was considered to be controlled by the diffusion through the liquid phase, and the values of the activation energy were $75 \mathrm{kcal} / \mathrm{mol}$ and $26 \mathrm{kcal} / \mathrm{mol}$ for the diffusion rate in the liquid phase of $\mathrm{V}_{2} \mathrm{O}_{5}$ and $\mathrm{B}_{2} \mathrm{O}_{3}$, respectively.
\end{abstract}

[Received December 25, 1974]

\section{1. 緒言}

$\mathrm{Zn}_{2} \mathrm{SnO}_{4}$ が逆スピネル型構造をとる酸化物であること は知られているが, その物理的, 化学的性質について は，他のスピネル型酸化物ほど十分に知られていない。 著者ら ${ }^{1,2}$ は, 気相法により $\mathrm{Zn}_{2} \mathrm{SnO}_{4}$ の単結晶の合成を 試み，比較的短時間核㞣に $\mathrm{Zn}_{2} \mathrm{SnO}_{4}$ 針状結晶を得た. また最近になって $\mathrm{Zn}_{2} \mathrm{SnO}_{4}$ の焼結体が linear resistor

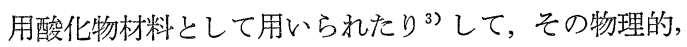
化学的性質について関心が向けられて来ている.一方, その構成酸化物である $\mathrm{ZnO}, \mathrm{SnO}_{2}$ の焼結が適去多く報 告 4 7)されているのに対し， $\mathrm{Zn}_{2} \mathrm{SnO}_{4}$ の焼結反応につい ては今までの所報告された例は見当らない。
本報では，先ず $\mathrm{Zn}_{2} \mathrm{SnO}_{4}$ の燒結反応を行い，その焼 結機構について考察を加え, さらに, この燒結に対する 種々の酸化物の添加の効果を調へ，その中で $\mathrm{V}_{2} \mathrm{O}_{5}, \mathrm{~B}_{2} \mathrm{O}_{3}$ が特に著し、効果を示したので，この両酸化物の添加効 果について検討した.

\section{2. 実験方法}

出発試料として使用した $\mathrm{ZnO}, \mathrm{SnO}_{2}$ は, 市販の特級 試薬である.この両試料を, $\mathrm{Zn}_{2} \mathrm{SnO}_{4}$ の化学量論比に 秤量し乳ばちで十分に混合して $400 \mathrm{~kg} / \mathrm{cm}^{2}$ の圧力で 20 $\mathrm{mm} \phi \times 2.4 \sim 2.5 \mathrm{~mm}$ の円板に成形（以下の成形体には すべて同じ条件を用いた）したもの，及びこの成形体を 
$1200^{\circ} \mathrm{C}$ で 2 時間予備焼成して粉砕した後, 再び成形し たものをそれぞれ焼結試料として用いた， $1200^{\circ} \mathrm{C}$ で予 備焼成した試料の粉末 $\mathrm{X}$ 線回折を行った結果, 回折図形 は $\mathrm{Zn}_{2} \mathrm{SnO}_{4}$ の単一相を示した。 また, そのほかに, 予 備焼成して得られた $\mathrm{Zn}_{2} \mathrm{SnO}_{4}$ 粉末に次の酸化物を 5 $\mathrm{wt} \%$ 加え, 十分に混合した成形体についても焼結を試 み, $\mathrm{Zn}_{2} \mathrm{SnO}_{4}$ の焼結に対する添加物の効果を調べた. 加 えた酸化物は, $\mathrm{PbO}, \mathrm{NiO}, \mathrm{CuO}, \mathrm{FeO}, \mathrm{CoO}, \mathrm{B}_{2} \mathrm{O}_{3}, \mathrm{Fe}_{2} \mathrm{O}_{3}$, $\mathrm{Cr}_{2} \mathrm{O}_{3}, \mathrm{CrO}_{3}, \mathrm{~V}_{2} \mathrm{O}_{5}, \gamma-\mathrm{Al}_{2} \mathrm{O}_{3}, \mathrm{Sb}_{2} \mathrm{O}_{3}, \mathrm{Li}_{2} \mathrm{CO}_{3}, \mathrm{MnO}_{2}$ で ある。

耐火物製の容器7)に成形体を入れたもの 5〜6 個を, $1200 \sim 1400^{\circ} \mathrm{C}$ の各温度に保った 電気炉中に急激に入れ て加熱後, 1 200 分間の間で所定の 時間毎に 1 個ずつ 取り出し $\mathrm{Zn}_{2} \mathrm{SnO}_{4}$ の燒結を行った. 耐火物容器に成形 体を入れる際には，原料と同じ粉末で成形体を覆いその 上から耐火物製の蓋をした. 加熱前後の成形体の径の寸 法から収縮率 $\left(\Delta L / L_{0}\right)$ を求め, 焼結速度を測定した. 成形体の径は, マイクロメーターで 5 点測定し, その平 均值から求めた。 なお, 成形体を所定温度に保った電気 炉中に挿入する際, 炉温度が一旦低下するので, 所定温 度に回復した時を焼結開始時間とした。また, 得られた 焼結体については, そのほかに嵩密度, 真密度を測定 し,この比から相対密度を求めた. 相対密度の高い燒結 体については, その破断面の微細構造をレプリカ法によ り電子顕微鏡で観察し, その粒成長の測定を行った.

\section{$3.1 \mathrm{Zn}_{2} \mathrm{SnO}_{4}$ の焼結}

図-1 は, $1200^{\circ} \mathrm{C}$ で予備焼成して得た $\mathrm{Zn}_{2} \mathrm{SnO}_{4}$ を 1200

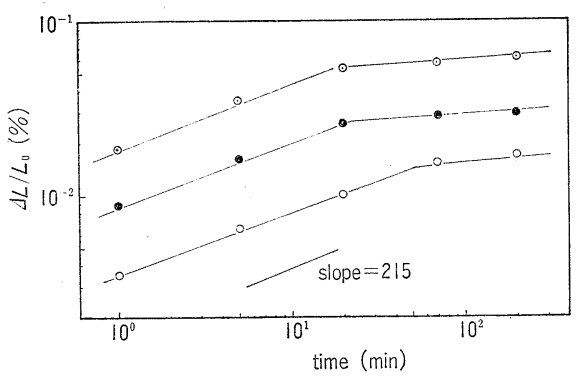

Fig. 1. Log shrinkage vs. log time for the sintered compacts of $\mathrm{Zn}_{2} \mathrm{SnO}_{4}$. $\bigcirc: 1200^{\circ} \mathrm{C}, 0: 1300^{\circ} \mathrm{C}$, ๑ : $1400^{\circ} \mathrm{C}$

$\sim 1400^{\circ} \mathrm{C}$ の温度範囲で燒結し, その結果得られた焼結 体の $\log \left(\Delta L / L_{0}\right)$ に対して $\log t(t$ : 時間) をプロット したものである。図のプロットは $2 つ の$ 直線部分から 成り立っていることが分る. また，この時得られた燒結 体の相対密度と焼結時間の関係を 図-2 に示した. Kingery $^{8)}, \mathrm{Coble}^{9), 10)}$ らによると, 焼結の初期段階は収縮 率でおよそ〜10\%，相対密度で～60\% に相当すると言

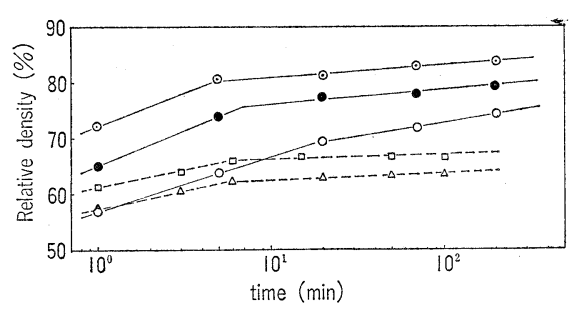

Fig. 2. Relative density vs. $\log$ time for the sintered compacts of $\mathrm{Zn}_{2} \mathrm{SnO}_{4}$.

$\bigcirc: 1200^{\circ} \mathrm{C}, \quad: 1300^{\circ} \mathrm{C}, \bigcirc: 1400^{\circ} \mathrm{C} \cdots \cdots$ sintered compacts of $\mathrm{Zn}_{2} \mathrm{SnO}_{4}$ $\triangle: 1300^{\circ} \mathrm{C}, \square: 1400^{\circ} \mathrm{C} \cdots \cdot . \cdot$ sintered compacts of mixtures of $\mathrm{ZnO}$ and $\mathrm{SnO}_{2}$ in stoichiometric ratio of $\mathrm{Zn}_{2} \mathrm{SnO}_{4}$

われており, 初期の焼結速度 は一般に次式で表わされ る.

$$
\begin{aligned}
& \left(\Delta L / L_{0}\right)^{1 / P}=K_{1} D t / T \\
& K_{1}=B r \delta^{3} / r^{m} k
\end{aligned}
$$
ここで, $D$ は拡散定数， $r$ は表面エネルギー， $\delta^{3}$ は空格 子体積, $r$ は粒径, $k$ はボルツマン定数, $T$ は絶対温 度, $P, B, m$ は焼結機構によって異なる 定数である. Kingery $ら^{8)}$ による, 初期焼結が体積拡散により進行 するならばPの值は理論的に $2 / 5$ となる. 図-1 におけ る前半の直線部分に注目すると, 収縮率は $0.3 \sim 5 \%$, 図-2 より相対密度は 57 ～ $80 \%$ となり，この直線の匂配 を求めると約 $2 / 5$ となった. 従って, 図-1 における前 半の直線部分は, 焼結の初期段階に相当し体積拡散によ

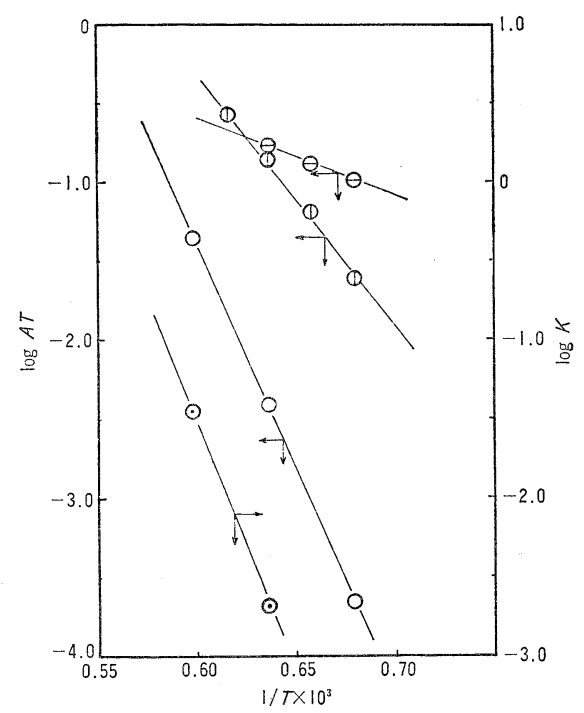

Fig. 3. Arrhenius plots for the shrinkage and the grain growth. shrinkage : $\bigcirc: \mathrm{Zn}_{2} \mathrm{SnO}_{4}, \quad(1): \mathrm{Zn}_{2} \mathrm{SnO}_{4}$ $+3 \mathrm{wt} \%-\mathrm{V}_{2} \mathrm{O}_{5}$, $\ominus: \mathrm{Zn}_{2} \mathrm{SnO}_{4}+2 \mathrm{wt} \%-\mathrm{B}_{2} \mathrm{O}_{3}$ grain growth : $\odot: \mathrm{Zn}_{2} \mathrm{SnO}_{4}$ 
って焼結が進行するものと思われる.図-3 は焼結の初 期段階における活性化エネルギーを求めるため，(3) 式 における $A=K_{1} D / T$ を 図-1 の各温度について求め, $\log A T$ の温度依存性についてプロットしたものであ る.これより, 焼結の初期段階における挔散の活性化工 ネルギーの值は $130 \mathrm{kcal} / \mathrm{mol}$ となった. 一般に, 酸化物 の焼結における酸素イオンの拡散の活性化エネルギーの

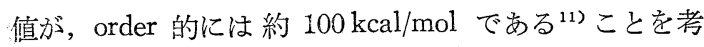

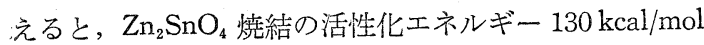
の值は, 酸素の拡散が律速であることを示すものと思わ れる.なお, 後半の直 線部分は, 図-2 の相対密度の值 より粒成長を伴った燒結の中期段階に相当するものとみ なせる ${ }^{10)}$.

図-4 $\mathrm{ZnO}$ と $\mathrm{SnO}_{2}$ の粉末試料を $\mathrm{Zn}_{2} \mathrm{SnO}_{4}$ の化 学量論比に混合したものの成形体を, $1250 \sim 1400^{\circ} \mathrm{C} の$ 温度範囲で焼結した結果走示した.この焼結体の相対密

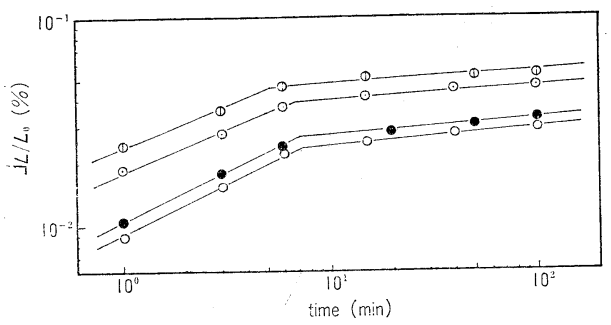

Fig. 4. Log shrinkage vs. log time for the sintered compacts of mixtures of $\mathrm{ZnO}$ and $\mathrm{SnO}_{2}$ in stoichiometric ratio of $\mathrm{Zn}_{2} \mathrm{SnO}_{4}$.

$\bigcirc: 1250^{\circ} \mathrm{C}$, : $: 1300^{\circ} \mathrm{C},(1): 1350^{\circ} \mathrm{C}$, (1) $: 1400^{\circ} \mathrm{C}$

度は 図-2 に示してある. 図-4 から, $\log \left(\Delta L / L_{0}\right)$ 対 $\log t$ のプロットは 2 つの直線部分から成ることが分か る.しかしながら, 初期焼結に相当すると思われる前半 の直線の勾配は, $1250^{\circ} \mathrm{C}, 1300^{\circ} \mathrm{C}, 1350^{\circ} \mathrm{C}, 1400^{\circ} \mathrm{C}$ で それぞれ $0.48 ， 0.47 ， 0.42 ０ .41$ と焼結温度により異 なり同一の焼結機構では説明できない. また 図-2 から 予備焼成した $\mathrm{Zn}_{2} \mathrm{SnO}_{4}$ と $\mathrm{ZnO}, \mathrm{SnO}_{2}$ の粉末試料の焼 結体の相対密度を比較すると, 明らかに後者の值は小さ い.これらのことは， $\mathrm{ZnO} と \mathrm{SnO}_{2}$ との反忘が初期の 焼結速度や相対密度の值に影響を与えていることを示す ものと思われる。

\section{$3.2 \mathrm{Zn}_{2} \mathrm{SnO}_{4}$ の焼結に及ぼす添加物の効果}

$1200^{\circ} \mathrm{C}$ で予備燒成して調製した $\mathrm{Zn}_{2} \mathrm{SnO}_{4}$ を焼結した 方が， $\mathrm{ZnO}$ と $\mathrm{SnO}_{2}$ との混合物を焼結したより相対密度 が高、結果が得られることが分かったので, 添加物の効
黨業協会誌 83 [8］ 1975403

果を調べるのに前者の試料を用いた. 表-1 は, この $\mathrm{Zn}_{2}$ $\mathrm{SnO}_{4}$ に $5 \mathrm{wt} \%$ の種々の酸化物を添加し $1300^{\circ} \mathrm{C}, 20$ 分 間大気中にて焼結した試料の相対密度と収縮率の值を示 したものである。この表より，添加による焼結の促進効 果を示すものとして $\mathrm{PbO}, \mathrm{B}_{2} \mathrm{O}_{3}, \mathrm{~V}_{2} \mathrm{O}_{5}, \mathrm{Li}_{2} \mathrm{CO}_{3}$ があげ られる。そこで, 特に高い相対密度の值 $92.0 \%, 91.1 \%$ を示したそれぞれ $\mathrm{V}_{2} \mathrm{O}_{5}$ と $\mathrm{B}_{2} \mathrm{O}_{3}$ の焼結の促進機構につ いて検討した。

図-5, 6 は， $\mathrm{Zn}_{2} \mathrm{SnO}_{4}$ に $\mathrm{V}_{2} \mathrm{O}_{5}, \mathrm{~B}_{2} \mathrm{O}_{3}$ をそれぞれ $3 \mathrm{wt} \%$ ，

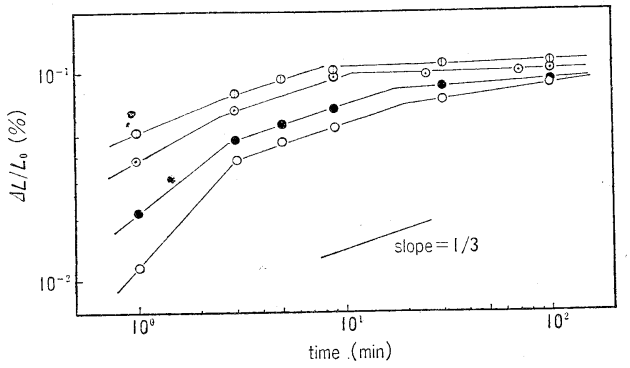

Fig. 5. Log shrinkage vs. log time for the sintered compacts of $\mathrm{Zn}_{2} \mathrm{SnO}_{4}$ with $3 \mathrm{wt} \%-\mathrm{V}_{2} \mathrm{O}_{5}$.

$\bigcirc: 1200^{\circ} \mathrm{C},: 1250^{\circ} \mathrm{C}, \odot: 1300^{\circ} \mathrm{C}$, (1) $: 1350^{\circ} \mathrm{C}$

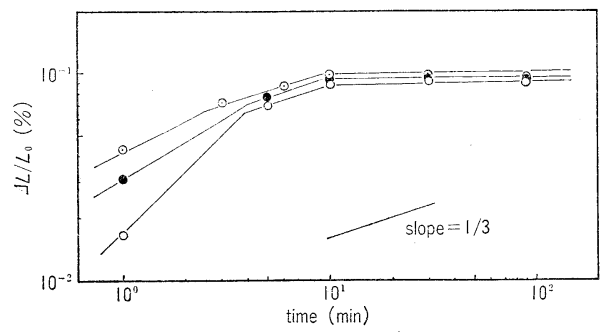

Fig. 6. Log shrinkage vs. log time for the sintered compacts of $\mathrm{Zn}_{2} \mathrm{SnO}_{4}$ with $2 \mathrm{wt} \%-\mathrm{B}_{2} \mathrm{O}_{3}$.

$\mathrm{O}: 1200^{\circ} \mathrm{C}, 1250^{\circ} \mathrm{C}, \odot: 1300^{\circ} \mathrm{C}$

$2 \mathrm{wt} \%$ 加え $1200 \sim 1350^{\circ} \mathrm{C}$ の温度範囲で焼結した 結 果 を示したものである.それぞれの $3 \mathrm{wt} \%, 2 \mathrm{wt} \%$ の添 加量は, 予備実験を行って求めた高い相対密度を与え, しかも, それ以上添加しても相対密度に増加が見られな かった添加量である.この時, 得られた燒結体の相対密 度を表-2,3 に示した. 図-1 と図-5,6 に㧍ける燒結 速度, 及び 図-2 と表- 2,3 における相対密度を比較す ると $\mathrm{Zn}_{2} \mathrm{SnO}_{4}$ の緻密化に対する $\mathrm{V}_{2} \mathrm{O}_{5}, \mathrm{~B}_{2} \mathrm{O}_{3}$ の效果が 著しいことが理解できる. $\mathrm{V}_{2} \mathrm{O}_{5}$ の融点は $690^{\circ} \mathrm{C}, \mathrm{B}_{2} \mathrm{O}_{3}$

Table 1. Relative density and $\Delta L / L_{0}$ of the sintered compacts of $\mathrm{Zn}_{2} \mathrm{SnO}_{4}$ with 5 wt\% oxide.

\begin{tabular}{|c|c|c|c|c|c|c|c|c|c|c|c|c|c|c|c|}
\hline Additive & non & $\mathrm{PbO}$ & $\mathrm{NiO}$ & $\mathrm{CuO}$ & $\mathrm{FeO}$ & $\mathrm{CoO}$ & $\mathrm{B}_{2} \mathrm{O}_{3}$ & $\mathrm{Fe}_{2} \mathrm{O}_{3}$ & $\mathrm{Cr}_{2} \mathrm{O}_{3}$ & $\mathrm{CrO}_{3}$ & $\mathrm{~V}_{2} \mathrm{O}_{5}$ & $\gamma-\mathrm{Al}_{2} \mathrm{O}_{3}$ & $\mathrm{Sb}_{2} \mathrm{O}_{3}$ & $\mathrm{Li}_{2} \mathrm{CO}_{3}$ & $\mathrm{MnO}_{2}$ \\
\hline R.D. (\%) & 77.4 & 82.6 & 76.9 & 76.1 & 75.9 & 77.3 & 91.1 & 78.0 & 71.7 & 72.0 & 92.0 & $71: 6$ & 72.3 & 80.0 & 76.4 \\
\hline$\Delta L / L_{0}(\%)$ & 2.58 & 6.45 & 1.10 & 2.19 & 1.06 & 0.76 & 9.75 & 2.79 & 1.23 & 1.31 & 12.06 & 0.63 & 1.42 & 4.61 & 1.87 \\
\hline
\end{tabular}

sintering condition: $1300^{\circ} \mathrm{C}, 20 \mathrm{~min}$. , in air. 
Table 2. Relative density of the sintered compacts of $\mathrm{Zn}_{2} \mathrm{SnO}_{4}$ with $3 \mathrm{wt} \% \mathrm{~V}_{2} \mathrm{O}_{5}$

\begin{tabular}{|c|c|c|c|c|c|c|c|c|c|c|c|c|c|c|c|c|c|c|c|c|c|c|c|c|}
\hline \multirow{2}{*}{$\begin{array}{l}\text { Temp. (C) } \\
\text { Time (min) }\end{array}$} & \multicolumn{6}{|c|}{1200} & \multicolumn{6}{|c|}{1250} & \multicolumn{6}{|c|}{1300} & \multicolumn{6}{|c|}{1350} \\
\hline & 1 & 3 & 5 & 9 & 30 & 100 & 1 & 3 & 5 & 9 & 30 & 100 & 1 & 3 & 9 & 25 & 70 & 150 & 1 & 3 & 5 & 9 & 30 & 100 \\
\hline R.D. $(\%)$ & 70.4 & 76.5 & 81.5 & 83.4 & 88.4 & 90.8 & 72.9 & 80.1 & 84.3 & 86.0 & 90.8 & 392.8 & 77.9 & 87.8 & 90.4 & 92.6 & 94.8 & 95.4 & 80.6 & 90.8 & 395.0 & 95.4 & 96.1 & 97.1 \\
\hline
\end{tabular}

Table 3. Relative density of the sintered compacts of $\mathrm{Zn}_{2} \mathrm{SnO}_{4}$ with $2 \mathrm{wt} \% \mathrm{~B}_{2} \mathrm{O}_{3}$

\begin{tabular}{|c|c|c|c|c|c|c|c|c|c|c|c|c|c|c|c|c|}
\hline Temp. ( $\left.{ }^{\circ} \mathrm{C}\right)$ & & & 1200 & & & & & 1250 & & & & & & 1300 & & \\
\hline Time (min) & 1 & 5 & 10 & 30 & 90 & 1 & 5 & 10 & 30 & 90 & 1 & 3 & 6 & 10 & 30 & 90 \\
\hline R.D. $(\%)$ & 79.5 & 93.1 & 95.6 & 96.1 & 97.0 & 82.5 & 94.4 & 96.4 & 97.0 & 97.1 & 6.0 & 94.0 & 95.7 & 96.9 & 97.4 & 97.6 \\
\hline
\end{tabular}

のそれは $577^{\circ} \mathrm{C}$ であり ${ }^{12)}$ ，また， $\mathrm{V}_{2} \mathrm{O}_{5}$ を添加した焼結 体は，焼結時間が長い程褐色となった．これらのことか ら， $\mathrm{V}_{2} \mathrm{O}_{5}, \mathrm{~B}_{2} \mathrm{O}_{3}$ が液相として作用していることが考え られる. 液相共存の燒結については, Kingery が提出し

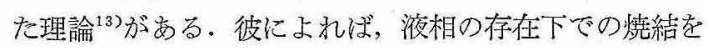
䊀子の微細構造の変化加ら捕え, 粒子の再配列, つづい て溶解一析出を経て最後に合体の 3 つの過程加ら成ると 説明している.さらに, 粒子の再配列, 溶解一析出, 合 体過程に㧍ける速度式は次の式で一般化される.

$$
\Delta L / L_{0}=K_{2} t^{m} \ldots
$$

定数 $K_{2}$ は, 溶解一析出過程において液相中の拡散が律 速な場合

$$
K_{2}=\left(6 k_{2} \delta D C_{0} r V_{0} / k_{1} R T\right)^{1 / 3} r^{-4 / 3}
$$

相境界での反応が律速な場合

$$
K_{2}=\left(2 k_{2} k_{4} \gamma C_{0} V_{0} / k_{1} R T\right)^{1 / 2} \gamma^{-1}
$$

となる. (5), (6) 式において $k_{1} \sim k_{4}$ は定数, 。梳 界の厚さ， $C_{0}$ は拡散物質の初期濃度， $V_{0}$ は粒子の初 期体積， R 注気体定数である。また（4）式の $m$ の值 は, 粒子の再配列過程では $m=y+1(y$ は 1 ら小さ 、数), 溶解一析出過程では, 液相中の拡散が律速な場 合， $m=1 / 3$, 相境界での反応が律速な場合, $m=1 / 2$, 合体過程では $m \ll 1$ となる。図 $-5,6$ より， $\mathrm{V}_{2} \mathrm{O}_{5}$ 及び $\mathrm{B}_{2} \mathrm{O}_{3}$ を添加した時の $\mathrm{Zn}_{2} \mathrm{SnO}_{4}$ の焼結速度をみると，い すれの場合の衸結も3 段階より成り立っていることが理 解できる.さらに, 第 $1 \sim 3$ 段㙫の直線の勾配, $m$, を 求めると，第 1 段階では，燒結温度が高くなると $m$ が小 さくなる傾向があるが $1200^{\circ} \mathrm{C}, 1250^{\circ} \mathrm{C}$ の温度では 0.8 $<m<1.1$, 第 2 段階では $m=1 / 3$ (拡散が律速で (5) 式 が成立), 第 3 段階では $0.02<m<0.12$ となった. 従っ て, $\mathrm{V}_{2} \mathrm{O}_{5}, \mathrm{~B}_{2} \mathrm{O}_{3}$ 攴添加した時の $\mathrm{Zn}_{2} \mathrm{SnO}_{4}$ の緻密化は,
Kingery が提出した液相共存の焼結機構で説明できるも のと考えられる. 即ら, 熔融した $\mathrm{V}_{2} \mathrm{O}_{5}, \mathrm{~B}_{2} \mathrm{O}_{3}$ 共存下で は, $\mathrm{Zn}_{2} \mathrm{SnO}_{4}$ 焼結初期で粒子の再.配列が起き, つうい $\tau$, 粒子驾 $\mathrm{V}_{2} \mathrm{O}_{5}, \mathrm{~B}_{2} \mathrm{O}_{3}$ 熔融体中に溶解し液相中を㹡散 することにより物質移動が容易となり,繖密化が進み, 最 後に合体過程で焼結が終る。ここで, 第 2 段階における 拡散の活性化エネルギーの值を(5) 式から 3.1 における. $\mathrm{Zn}_{2} \mathrm{SnO}_{4}$ 単独の焼結の場合と同様にして求的ると（図一 3), $\mathrm{V}_{2} \mathrm{O}_{5}$ の場合 $75 \mathrm{kcal} / \mathrm{mol}, \mathrm{B}_{2} \mathrm{O}_{3}$ の場合 $26 \mathrm{kcal} / \mathrm{mol}$ となった。この值は, $\mathrm{Zn}_{2} \mathrm{SnO}_{4}$ 単独の初期焼結におけ る体積昖散の活性化エネルギーの值 $130 \mathrm{kcal} / \mathrm{mol}$ と比 較するとかなり小さい。このことからも， $\mathrm{V}_{2} \mathrm{O}_{5}, \mathrm{~B}_{2} \mathrm{O}_{3}$ 添加の場合の第 2 段階に晾汸律段階が液相中での桩 散であることが推定される。

次に, $\mathrm{V}_{2} \mathrm{O}_{5}, \mathrm{~B}_{2} \mathrm{O}_{3}$ を添加して得られた焼結体の微細 構造を電子顕微鏡で観察した。図-7 (a) は， $\mathrm{V}_{2} \mathrm{O}_{5}$ を添 加し $1300^{\circ} \mathrm{C}, 70$ 分間の条件で得られた焼結体（相刘密 度 : $94.8 \%$ ）の電子䫓微鏡写真である.この場合, $\mathrm{V}_{2} \mathrm{O}_{5}$ が水に嚾かに溶解するため，燒結体の破断面について顯 微鏡観察を行った. 図一 7 (b) は, $\mathrm{B}_{2} \mathrm{O}_{3}$ を添加し $1300^{\circ} \mathrm{C}$, 30分閒の条件で得られた焼結体（相対密度：97.4\%)の 表面をダイヤモンドペーストで研磨し，3 分閒熱硫酸で エッチングした電子顕 微鏡写真である. 比較のため, 図-7 (c) に $1400^{\circ} \mathrm{C}, 20$ 分閒の条件で得られた $\mathrm{Zn}_{2} \mathrm{SnO}_{4}$ 単独の兟結体 (相対密度 : $81.2 \%$ ) の破断面を示した。 図-7 (a) から， $\mathrm{Zn}_{2} \mathrm{SnO}_{4}$ 粒子間に $\mathrm{V}_{2} \mathrm{O}_{5}$ が 熔融して流 動したと思われる形跡が観察される.また，この場合の 䊀形は比較的 spheroidal な形をしているが，一般には 図-7 (c) の場合の角張った形をしていた。図-7 (b) か ら, $\mathrm{B}_{2} \mathrm{O}_{3}$ 添加では, $\mathrm{Zn}_{2} \mathrm{SnO}_{4}$ の grain boundary 及び.
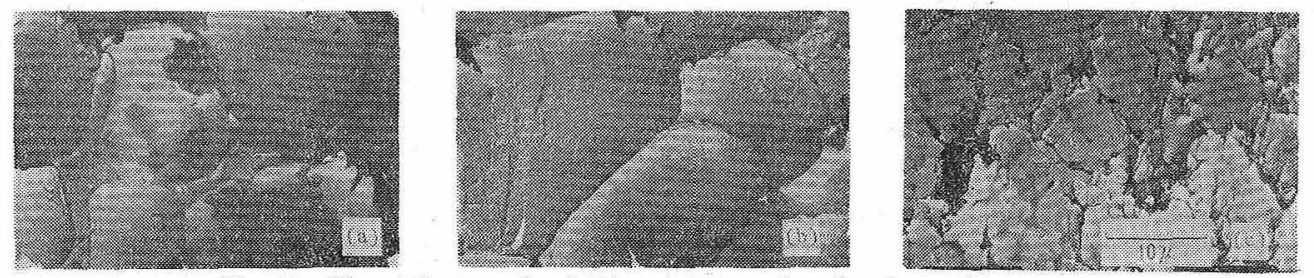

Fig. 7. Photomicrograph of microstructure for the sintered compact.

(a) $\mathrm{Zn}_{2} \mathrm{SnO}_{4}+3 \mathrm{w} \% \mathrm{~V}_{2} \mathrm{O}_{5}: 1300^{\circ} \mathrm{C}, 70 \mathrm{~min}$.

(b) $\mathrm{Zn}_{2} \mathrm{SnO}_{4}+2 \mathrm{wt} \%-\mathrm{B}_{2} \mathrm{O}_{3}: 1300^{\circ} \mathrm{C}, 30 \mathrm{~min}$ (after $\mathrm{H}_{2} \mathrm{SO}_{4}$ etch).

(c) $\mathrm{Zn}_{2} \mathrm{SnO}_{4}: 1400^{\circ} \mathrm{C}, 20 \mathrm{~min}$. 
39 松下徹涼か

粒子表面の一部が熔融した $\mathrm{B}_{2} \mathrm{O}_{3}$ で侵されたと思われる 形跡を示し, また, 粒形は $\mathrm{Zn}_{2} \mathrm{SnO}_{4}$ 単独と比較して液相 共存の燒結に特有な spheroidal であることが分かる. これらのことから， $\mathrm{V}_{2} \mathrm{O}_{5}, \mathrm{~B}_{2} \mathrm{O}_{3}$ を添加した場合, これ らが熔融状態で, $\mathrm{Zn}_{2} \mathrm{SnO}_{4}$ の焼結に対して著しい促進 作用を及ぼしていることが裏付けられる.なお， $\mathrm{V}_{2} \mathrm{O}_{5}$, $\mathrm{B}_{2} \mathrm{O}_{3}$ 添加における粒形の違いは, $\mathrm{V}_{2} \mathrm{O}_{5}, \mathrm{~B}_{2} \mathrm{O}_{3}$ 融体中へ の $\mathrm{Zn}_{2} \mathrm{SnO}_{4}$ の溶解度の差異, さらには融体の粘性, 濡 れ等の違いによるものと考えられる. また, この違いが 焼結速度に影響を与えると考えれば, $\mathrm{V}_{2} \mathrm{O}_{5}, \mathrm{~B}_{2} \mathrm{O}_{3}$ 添加 における拡散の活性化エネルギーの違いが説明されると 思われる。

\section{$3.3 \mathrm{Zn}_{2} \mathrm{SnO}_{4}$ の粒成長}

3.1 で 図-1 の後半の直線部分は相対密度の值が $70 \%$ 以上の粒成長を伴った焼結の中期段階に相当することを 述べた. また, 表-2,3 における $90 \%$ 以上の相対密度の 值の場合は, 液相共存における合体に対応した過程に相 当することが分かった，そこで, 次にこれら相対密度の 高い段階での粒成長を測定した。

図-8 は, $\mathrm{Zn}_{2} \mathrm{SnO}_{4}$ 単独, $\mathrm{V}_{2} \mathrm{O}_{5}, \mathrm{~B}_{2} \mathrm{O}_{3}$ を添加した場合

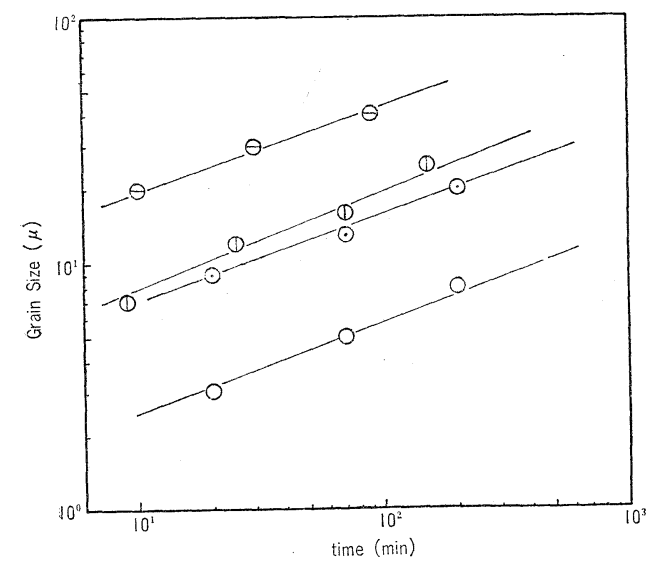

Fig. 8. Grain growth of $\mathrm{Zn}_{2} \mathrm{SnO}_{4}$.

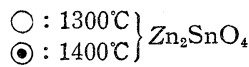
$\ominus: 1300^{\circ} \mathrm{C}, \mathrm{Zn}_{2} \mathrm{SnO}_{4}+2 \mathrm{wt} \%-\mathrm{B}_{2} \mathrm{O}_{3}$
(1): $1300^{\circ} \mathrm{C}, \mathrm{Zn}_{2} \mathrm{SnO}_{4}+3 \mathrm{wt} \%-\mathrm{V}_{2} \mathrm{O}_{5}$

の $\mathrm{Zn}_{2} \mathrm{SnO}_{4}$ 焼結体の粒径を焼結時間に対してプロット したものである. 粒径は, 電子顕微鏡の観察から求め た. 図-8.より, 明らかに $\mathrm{V}_{2} \mathrm{O}_{5}, \mathrm{~B}_{2} \mathrm{O}_{3}$ を添加した場合, $\mathrm{Zn}_{2} \mathrm{SnO}_{4}$ 単独よりも粒成長速度が大きいことが分かる. 粒成長速度は, 経験的に次式で表わされる ${ }^{14)}$.

$$
D^{n}=K_{3} t
$$

ここで, $D$ は平均粒径, $n$ は定数, $K_{3}$ は速度定数であ る. $n$ の值は, 理論的には粒成長速度が粒径に逆比例す るということから $n=2$ と導かれるが, 実際には, 粒子 中に存在する気孔や不純物等の影響により $n>2$ とな る. 図-8の $\log D$ vs. $\log t$ の直線の勾配は, いずれの
窐業協会誌 83 [8] 1975405

場合も $n \simeq 3$ となり, 既に多くの粒成長の研究で報告さ れている值と一致した ${ }^{15 \sim 17)}$. 次に, $\mathrm{Zn}_{2} \mathrm{SnO}_{4}$ 単独の場 合の $1300^{\circ} \mathrm{C}, 1400^{\circ} \mathrm{C}$ に㧍ける $K_{3}$ の值を計算し, この 2 点間でアレニウスの関係が成立するものと仮定して活 性化エネルギーを求めると, およそ $150 \mathrm{kcal} / \mathrm{mol}$ とな った。この值は, 初期段階にお打る体積拡散の值 130 $\mathrm{kcal} / \mathrm{mol}$ と order 的に等しい. 従って, $\mathrm{Zn}_{2} \mathrm{SnO}_{4}$ 粒子 も体積拡散が律速となり成長していくものと推定され る. $\mathrm{V}_{2} \mathrm{O}_{5}, \mathrm{~B}_{2} \mathrm{O}_{3}$ 添加の場合は, $n=3$ となったこと, こ れら酸化物が液相と共存することから, Greenwood が 提出した液相共存の時の粒成長則 ${ }^{18}$ に従うもの亡考えら れる. $\mathrm{Zn}_{2} \mathrm{SnO}_{4}$ 単独と比較して, $\mathrm{V}_{2} \mathrm{O}_{5}, \mathrm{~B}_{2} \mathrm{O}_{3}$ 添加の場 合の大きな粒戒長速度は, 前述のように, 粒子の溶解一 析出過程が一部の粒子間でくり返されているためと考え られる。

\section{4. 総 括}

予備焼成して得られた $\mathrm{Zn}_{2} \mathrm{SnO}_{4}$ の成形体を, 1200 $1400^{\circ} \mathrm{C}, 1 \sim 200$ 分間の条件で燒結し, 収縮率 $\Delta L / L_{0}$ を 測定した結果, 焼結は初期段階で (1) 式に従い体積拡散 が律速となって進行するものと考えられ，この時の拡散 の活性化エネルギーの值は $130 \mathrm{kcal} / \mathrm{mol}$ であった. ま た, 焼結の中期以降における粒成長を測定した結果, 粒 成長は (7) 式に従い，活性化エネルギー約 $150 \mathrm{kcal} / \mathrm{mol}$ の值が得られた.この粒成長の場合も, 焼結の初期段階 と同じく体積拡散が律速となって進行するものと推定さ れた。

$\mathrm{Zn}_{2} \mathrm{SnO}_{4}$ に種々の酸化物を $5 \mathrm{wt} \%$ 添加し, $1300^{\circ} \mathrm{C}$, 20 分閒焼結した結果, $\mathrm{V}_{2} \mathrm{O}_{5}$ と $\mathrm{B}_{2} \mathrm{O}_{3}$ が焼結に対して著 しい促連効果を示すことが分かった. この $\mathrm{V}_{2} \mathrm{O}_{5}, \mathrm{~B}_{2} \mathrm{O}_{3}$ を $\mathrm{Zn}_{2} \mathrm{SnO}_{4}$ にそれぞれ $3 \mathrm{wt} \%, 2 \mathrm{wt} \%$ 添加し，1200 $1300^{\circ} \mathrm{C}$ の温度範团で焼結し, 焼 結 速度を求めた結果, これら酸化物が熔融状態で焼結を著しく促進しているこ とが明らかとなった. 即ち, この促進作用は, 第 1 段階 で $\mathrm{Zn}_{2} \mathrm{SnO}_{4}$ 粒子の再配列つづいて第 2 段階の溶解, 挔 散, 析出過程を経るものと考えられ, しかも2 第段階で は液相中に溶解した $\mathrm{Zn}_{2} \mathrm{SnO}_{4}$ の拡散が律速となって進 行する.この拡散の活性化エネルギーは, $\mathrm{V}_{2} \mathrm{O}_{5}$ 添加の 場合 $75 \mathrm{kcal} / \mathrm{mol}, \mathrm{B}_{2} \mathrm{O}_{3}$ 添加の場合 $26 \mathrm{kcal} / \mathrm{mol}$ であっ た.これらのことの一部は, 得られた焼結体の破断面及 び表面の電子顕微鏡の観察から説明できた.

（昭和 49 年 7 月 25 日, 東北北海道支部 1974 年夏季研究発表 会で講演）

\section{文献}

1) M. Trömel, Z. Anorg. Allg. Chem., 387, 346 (1972).

2）松下徹, 山井嚴, 吉田諒一, 吉田雄次, 第 16 回人工鉱物 討論会講演要旨集 (1971) p. 13.

3) P.U.S.S.R. 198436, June, 28 (1967). 
4) L.D. Loch, J. Electrochem. Soc., 110, 1081 (1963).

5) G.C. Nicholson, J. Am. Ceram. Soc., 48, 214 (1965).

6) D. Dollimore and P. Spooner, Trans. Faraday Soc., 67, 2750 (1971).

7) 松下徹, 山井螈, 窯協, 80, 305 (1972).

8) W.D. Kingery and M. Berg, J. Appl. Phys., 26, 1205 (1955).

9) R.L. Coble and J.E. Burke, "Progress in Ceramic Science", Pergamon Press, Oxford-London (1963) p. 199.

10) R.L. Coble, J. Appl. Phys., 32, 787 (1961).

11) W.C. Hagel, P.J. Jorgensen and D.S. Tomalin,
J. Am. Ceram. Soc., 49, 23 (1966).

12）日本化学会編, “化学便覧, 基礎編 I”, 丸善 (1966).

13) W.D. Kingery, J. Appl. Phys., 30, 301 (1959).

14) R.L. Coble, J. Appl. Phys., 32, 793 (1961).

15) A.U. Daniels, R.C. Lowrie, R.L. Gibby and I.B. Cutler, J. Am. Ceram. Soc., 45, 282 (1962).

16) N.A.L. Mansour and J. White, Powder Met., 1963, No. 12, p. 108.

17) R.M. Spriggs, L.A. Brissette and T. Vasilos, ibid., 47, 417 (1964).

18) G.W. Greenwood, Acta Met., 4, 243 (1959).

(12/25/1974 受付) 